years, with the studonts spending alternately six months at the College and then six months in industry. It is intended that the students should be recruited from school and not be released from industry in order to attend the College. $£ 175$ has beon granted to Mr. S. H. Heath, a lecturer in plastics technology at the Birmingham College, to enable him to visit firms in Europe for three months and study and report on recent developments in new materials and polymerization processes. Funds have been provided for a research studentship in plastics technology, worth $£ 300$ a year for two years, at the Acton Technical College, London. A grant of $£ 500$ for the purchase of equipment for tearhing plastics technology has been made to the Cardiff College of Technology and Commerce, where a courso learding to the diplome of the Plastics Institute was started last Soptomber and where it is hoped to establish shortly a course for the associateship. There will again be available from the Fund a sum of $£ 1,000$ for training grants to young men or women working in the plastics industry to study full-time for a degree in science or engineering, and this year applications will be considered also for assistance to take a full-time course in industrial design.

\section{Magnetic Resonance : Symposium at Bangor}

A symposium on magnetic resonance, arranged by the Liverpool and North Wales Branch of the Institute of Physics, will be held in the Cniversity College of North Wales, Bangor, during Soptember 26-27. Lectures will be given by the following: Dr. B. Bleaney (Clarendon Laboratory, Oxford), free atom resonance; Dr. J. G. Powles (Queen Mary College, London), spin echo techniques; Dr. R. E. Richards (Department of Physical Chemistry, Oxford), magnets ; and Prof. E. R. Andrew (University College, Bangor), nucloar magnetic resonance work and other research at Bangor. At the symposium consideration will be given to the formation of $a$ group to provido future occasional meetings. Further information can be obtained from Prof. F. R. Andrew, Physics Department, University College of North Wales, Bangor, Caornarvonshire.

\section{Announcements}

A. S. P. DA Silva has been appointed by the Brazilian Ministry of Agriculture to be chief of the Experimental Station at Polotas.

DR. J. B. M. CopPock, director of the British Baking Industries Research Association, Chorley. wood, Herts, and Dr. C. R. Jones, of the Research Association of British Flour Millers, Old London Road, St. Albans, Horts, have been appointed corresponding editors for Great Britain of Cereal Science Today, the new journal of the American Association of Cereal Chemists. They would be glad to roceive nows of events or developments of potential interest to readers of the new journal.

The Oliver Memorial Fund is offering an award of $£ 50$ to a British subject for original work or services in connexion with the research, organization or donor aspect of blood transfusion. Applications or information on possible candidates for the award should be sent before September 30 to the Honorary Treasurer of the Fund, e/o National Provincial Bank, Ltd., Holborn Circus, London, E.C.1.

THF Chemical Society is offering grants from its Research Fund for tho assistance of research in all branches of chemistry. About $£ 700$ a year is available for this purpose, the income being derived from a donation of the Worshipful Company of Goldsmiths, from the Perkin Memorial Fund, and from other sources. Applications for grants should be submitted not later than November 15 to the Goneral Socretary of the Chemical Society at Burlington House, Piccadilly, London, W.1.

THE Committee on Stiatisties of the University of Chicago is offering a number of post-doctoral awards for study in statistics by porsons whose primary field is not statistics but one of the physical, biological, or social sciences to which statistics can be applied. The awards are for the academic year 1957-58 and are worth 3,600-5,000 dollars. Application should be made before February 15, 1957, to the Committee on Statistics, Eckhart Hall, University of Chicago, Chicago 37, Ill.

THE British Socioty of Rheology will hold a conferonce on "Extrusion and Rolling Processes" during September 27-28 in the Stephenson Hall of the University of Sheffield. Six papers will be read, covering various aspects of the rheology of motals and of plastics. Furthor information can be obtained from the Honorary Secrotary of the Society at 52 Tavistock Road, Edgware, Middlesex.

THF Iron and Steel Enginoers Group of the Iron and Stoel Instituto will hold a mooting in South Wales during October 4-5. During the mornings, papers will bo read in the (Grand Pavilion, Porthcawl. In the afternoons, visits will be made to the Margam Works (blast furnaces, coke ovens and sinter plant) and the Abbey Works (open-hearth steel plant and wide strip mills), respectively, of the Steel Company of Wales, Ltd. Application forms, to bo completed by Soptember 10, and further information can bo obtained from the Secretary of the Institute at 4 (Trosvenor Gardens, Isondon, S.W.1.

The third British Woed Control Conference, organized by the British Woed Control Council, will be hold in the Norbreck Hydro, Blackpool, during November 6-8. There will be two genoral discussions on the first day : one on whether weedkillers are being devoloped and used for ensuring efficient food production, and the other on wild oats. 'The subsequent days will be devoted to the reading of research reports. Further information can bo obtainod from W. A. Williams, British Weed Control Council, Cecil Chambers, 86 Strand, London, W.C.2.

THRWe awards have recently been made from the Mental Health Research Fund, as follows : a grant of $£ 200$ to Dr. James A. Hislop, of the Department of Human Ecology and University Health Service, Cambridge, for investigation of the length of stay of patients admitted to Fulbourn Fospital from the Islo of Ely during the past hundred years ; a Loverhulme grant of $£ 1,000$ a year for two years to the University of Leeds towards the cost of a senior research fellowship awarded to Dr. Max Hamilton, senior lecturer in the Department of Psychiatry, for work on the treatment of paranoid disorders by electro-convulsive therapy and insulin shock ; and a travelling fellowship of $£ 1,150$ to Dr. R. P. IJullin, lecturer in the Department of Biochemistry, University of Leeds, to spend a year in the Department of Physiological Chemistry, University of Pennsylvania, investigating now biochemical methods which may be applied to tho study. of the blood in manic-depressive psychoses and endogenous dopression. 